\title{
Chronic Pulmonary Thromboembolism Pathologically Showing Homogeneous Cellular Alveolitis
}

\author{
Seiichi Miwa ${ }^{1}$, Masahiro Shirai ${ }^{1}$, Shigeru Kobayashi ${ }^{2}$, Yusuke Kaida ${ }^{3}$, Takafumi Suda ${ }^{3}$, \\ Hiroshi Hayakawa ${ }^{1}$ and Kingo Chida ${ }^{3}$
}

\begin{abstract}
A 60-year-old man was admitted to our hospital complaining of general malaise. Examination of arterial blood gases on room air revealed hypoxia. Pulmonary function test showed restrictive abnormality. Chest high-resolution CT showed diffuse mosaic attenuation without evident pulmonary artery abnormality on contrast chest CT. Based on these findings, interstitial pneumonia or chronic pulmonary thromboembolism was suspected. The findings of bronchoalveolar lavage revealed $4.4 \times 10^{5}$ cells $/ \mathrm{mL}$, including $89.6 \%$ macrophages, 9.4\% lymphocytes, and $1.0 \%$ neutrophils. TBLB showed marked alveolitis. Moreover video-assisted thoracoscopic surgical biopsy was performed. Biopsies of the lung specimen showed focal infarct with surrounding mild mononuclear cell infiltrates (homogenous cellular alveolitis). ${ }^{99 \mathrm{~m}} \mathrm{Tc}$ pulmonary perfusion and ${ }^{81 \mathrm{~m}} \mathrm{Kr}$ ventilation scintigraphy showed V/Q mismatch. Furthermore, pulmonary angiography also revealed inadequate artery flow corresponding to the mismatch area of scintigraphy. Collagen vascular diseases and abnormality of coagulation factors were not detected. Multiple perfusion defects persisted for more than 6 months. Thus, finally the patient was diagnosed with chronic pulmonary thromboembolism, pathologically showing homogenous cellular alveolitis.
\end{abstract}

Key words: chronic pulmonary thromboembolism, cellular alveolitis, interstitial pneumonia, high-resolution $\mathrm{CT}$, mosaic attenuation, surgical biopsy

(Intern Med 50: 2195-2200, 2011)

(DOI: 10.2169/internalmedicine.50.5410)

\section{Introduction}

It is known that venous/pulmonary thromboembolism is associated with interstitial pneumonia (1-5). Here, we describe a case of chronic pulmonary thromboembolism (CPTE), radiographically showing mosaic attenuation and pathologically showing homogenous cellular alveolitis.

\section{Case Report}

A 60-year-old man was admitted to our hospital complaining of general malaise. He had been well until 10 days earlier, except for subtotal gastrectomy due to gastric cancer at the age of 40 years old. He was a never-smoker and had no dust/allergen exposure such as pets, birds, drugs, or molds in his occupational life or in his lifestyle. On physical examination, he was afebrile, and his respiratory and heart sounds were normal. Laboratory data on admission is shown in Table 1. Positive findings showed the following: hemoglobin was $7.1 \mathrm{~g} / \mathrm{dL}$ due to iron deficiency (the source of bleeding not determined), C-reactive protein $1.55 \mathrm{mg} / \mathrm{dL}$, brain natriuretic peptide (BNP) $321.7 \mathrm{pg} / \mathrm{mL}$ and D-dimer $3.0 \mathrm{mg} / \mathrm{dL}$ (LIAS AUTO D-Dimer $\mathrm{NEO}^{\circledR}$ Sysmex; normal range $<1.0 \mathrm{mg} / \mathrm{dL}$ ). Examination of arterial blood gases (ABG) on room air revealed $\mathrm{pH}, 7.508 ; \mathrm{PaCO}_{2}, 32.4$ torr; $\mathrm{PaO}_{2}, 56.7$ torr; $\mathrm{HCO}_{3}, 25.2 \mathrm{mmol} / \mathrm{L}$. Pulmonary function test (PFT) showed restrictive abnormality with decreased VC $2.23 \mathrm{~L}$ (\%VC 64.3\%), FVC $2.7 \mathrm{~L}$ (\%FVC 77.8\%) and DLco 58.8\%. Chest X-ray showed infiltrative shadow in the left upper lung field with cardiomegaly (Fig. 1A). Chest HRCT showed diffuse mosaic attenuation (Fig. 1B, C) with-

${ }^{1}$ Department of Respiratory Medicine, Tenryu Hospital, National Hospital Organization, Japan, ${ }^{2}$ Department of Radiology, Jichi Medical University, Japan and ${ }^{3}$ Department of Respiratory Medicine, Hamamatsu University School of Medicine, Japan

Received for publication February 26, 2011; Accepted for publication June 27, 2011

Correspondence to Dr. Seiichi Miwa, hirosei@za.tnc.ne.jp 
Table 1. Laboratory Data

\begin{tabular}{|c|c|c|c|c|}
\hline \multicolumn{2}{|l|}{ Hematology } & \multicolumn{3}{|l|}{ Pulmonary function tests } \\
\hline WBC & $8600 / \mu \mathrm{L}$ & $\mathrm{VC}$ & $2.23 \mathrm{~L}$ & $64.3 \%$ \\
\hline Neut & $81.9 \%$ & IRV & $0.46 \mathrm{~L}$ & \\
\hline Lym & $12.8 \%$ & TV & $1.09 \mathrm{~L}$ & \\
\hline Mono & $5.1 \%$ & ERV & $0.68 \mathrm{~L}$ & \\
\hline $\mathrm{RBC}$ & $422 \times 10^{4} / \mu \mathrm{L}$ & IC & $1.62 \mathrm{~L}$ & \\
\hline $\mathrm{Hb}$ & $7.1 \mathrm{~g} / \mathrm{dL}$ & $\mathrm{FVC}$ & $2.7 \mathrm{~L}$ & $77.8 \%$ \\
\hline Het & $26.2 \%$ & $\mathrm{FEV}_{1.0}$ & $2.39 \mathrm{~L}$ & $87.5 \%$ \\
\hline Platelet & $40.3 \times 10^{4} / \mu \mathrm{L}$ & $\mathrm{FEV}_{1.0} / \mathrm{FVC}$ & $88.5 \%$ & \\
\hline Serology & & DLCO & $10.37 \mathrm{~mL} / \mathrm{min} / \mathrm{mmHg}$ & $58.8 \%$ \\
\hline GOT & $17 \mathrm{IU} / \mathrm{L}$ & FRC & $3.34 \mathrm{~L}$ & $89.3 \%$ \\
\hline GPT & $12 \mathrm{IU} / \mathrm{L}$ & RV & $2.26 \mathrm{~L}$ & $166.2 \%$ \\
\hline LDH & $269 \mathrm{IU} / \mathrm{L}$ & TLC & $4.89 \mathrm{~L}$ & $90.4 \%$ \\
\hline ALP & $250 \mathrm{IU} / \mathrm{L}$ & RV/TLC & $54.4 \%$ & \\
\hline$\gamma \mathrm{GTP}$ & $23 \mathrm{IU} / \mathrm{L}$ & Arterial blood gas (room air) & & \\
\hline CPK & $79 \mathrm{IU} / \mathrm{L}$ & $\mathrm{pH}$ & 7.508 & \\
\hline T.Bil & $0.91 \mathrm{mg} / \mathrm{dL}$ & $\mathrm{PaCO}_{2}$ & 32.4 Torr & \\
\hline TP & $7.5 \mathrm{~g} / \mathrm{dL}$ & $\mathrm{PaO}_{2}$ & 56.7 Torr & \\
\hline $\mathrm{Alb}$ & $3.2 \mathrm{~g} / \mathrm{dL}$ & $\mathrm{HCO}_{3}^{-}$ & $25.2 \mathrm{mmol} / \mathrm{L}$ & \\
\hline $\mathrm{Na}$ & $137 \mathrm{mEq} / \mathrm{L}$ & Coagulation & & \\
\hline K & $4.0 \mathrm{mEq} / \mathrm{L}$ & PT & $70.5 \%$ & \\
\hline $\mathrm{Cl}$ & $105 \mathrm{mEq} / \mathrm{L}$ & PT-INR & 1.2 & \\
\hline BUN & $18.1 \mathrm{mg} / \mathrm{dL}$ & APTT & $33.9 \mathrm{sec}$ & \\
\hline $\mathrm{Cr}$ & $0.76 \mathrm{mg} / \mathrm{dL}$ & D-D dimer & $3.0 \mu \mathrm{g} / \mathrm{dL}$ & \\
\hline CRP & $1.55 \mathrm{mg} / \mathrm{dL}$ & Protein $\mathrm{C}$ antigen & $70 \%$ & $70-150$ \\
\hline Feritin & $11 \mathrm{ng} / \mathrm{mL}$ & Protein $\mathrm{C}$ activity & $72 \%$ & $64-146$ \\
\hline $\mathrm{s}-\mathrm{Fe}$ & $15 \mu \mathrm{g} / \mathrm{dL}$ & Protein $\mathrm{S}$ antigen & $81 \%$ & $65-135$ \\
\hline UIBC & $401 \mu \mathrm{g} / \mathrm{dL}$ & Protein S activity & $94 \%$ & $60-150$ \\
\hline $\operatorname{IgG}$ & $1753 \mathrm{mg} / \mathrm{dL}$ & Lupus anticoaglant & $44.9 \mathrm{sec}$ & $<55.5$ \\
\hline $\operatorname{IgA}$ & $330 \mathrm{mg} / \mathrm{dL}$ & anti-cardiolipin & negative & \\
\hline $\operatorname{IgM}$ & $604 \mathrm{mg} / \mathrm{dL}$ & Bronchoalveolar lavage & & \\
\hline $\mathrm{RF}$ & negative & Total cell count & $4.4 \times 10^{5} \quad$ cells $/ \mathrm{mL}$ & \\
\hline ANA & negative & Macrophage & $89.6 \%$ & \\
\hline anti SSA & negative & Lymphocyte & $9.4 \%$ & \\
\hline anti SSB & negative & Neutrophil & $1.0 \%$ & \\
\hline PR3-ANCA & negative & $\mathrm{CD} 4 / 8$ & 2.48 & \\
\hline MPO-ANCA & negative & & & \\
\hline KL-6 & $205 \mathrm{U} / \mathrm{mL}$ & & & \\
\hline SP-D & $38.6 \mathrm{ng} / \mathrm{mL}$ & & & \\
\hline BNP & $321.7 \mathrm{pg} / \mathrm{mL}$ & & & \\
\hline
\end{tabular}

out evident pulmonary artery abnormality on contrast chest CT. From the results of several examinations on admission, the clinically suspected diagnosis was small airway disease, interstitial pneumonia, and chronic pulmonary thromboembolism. Since deep vein thrombosis (DVT) was not detected by contrast lower extremity venography and PFT did not show obstructive abnormality except for RV/TLC, the patient was suspected of interstitial pneumonia and then underwent a bronchoscopy. The findings of bronchoalveolar lavage revealed $4.4 \times 10^{5}$ cells $/ \mathrm{mL}$, including $89.6 \%$ macrophages, $9.4 \%$ lymphocytes, and $1.0 \%$ neutrophils. TBLB showed marked alveolitis. One month after admission, hemoglobin rose to $10.3 \mathrm{~g} / \mathrm{dL}$ with oral iron therapy, but because HRCT, PFT and ABG were unchanged, video-assisted thoracoscopic surgical biopsy was performed. The lung specimen from right S8 showed focal infarct with surrounding mild mononuclear cell infiltrates (homogenous cellular alveolitis) (Fig. 2C, D), while right $\mathrm{S} 3$ showed slight mononuclear cell infiltrates without infarction (Fig. 2A, B). ${ }^{99 \mathrm{~m}} \mathrm{Tc}$ pulmonary perfusion and ${ }^{81 \mathrm{~m}} \mathrm{Kr}$ ventilation scintigraphy showed multiple V/Q mismatch. Furthermore, pulmonary angiography also revealed inadequate artery flow corresponding to the mismatch area of scintigraphy (Fig. 2E, F, G). Collagen vascular diseases and abnormality of coagulation factors (protein $\mathrm{C}$, protein $\mathrm{S}$, anti-cardiolipin antibody and lupus anticoagulant) were not detected. Two months after hospitalization, under informed consent the patient received only anticoagulant therapy (warfarin therapy). We considered that this patient, who had a slowly progressive condition with no clear history of an acute pulmonary thromboembolic event, so-called latent type chronic pulmonary thromboembolism (CPTE), had an exacerbation of this condition 10 days before admission. Additionally, multiple perfusion defects persisted for more than 6 months, as shown by a ventilation/perfusion (V/Q) lung scan (Supplement Fig. 1). Taken together, we finally diagnosed this patient with CPTE. Over ten months after the therapy, PFT (VC 3.45 L (\%VC 99.4\%), FVC 3.57 L (\%FVC 102.9\%) and DLco $109.6 \%$ ) were completely improved, while ABG on room air $\left(\mathrm{pH}, 7.440 ; \mathrm{PaCO}_{2}, 39.2\right.$ torr; $\mathrm{PaO}_{2}, 70.3$ torr; 


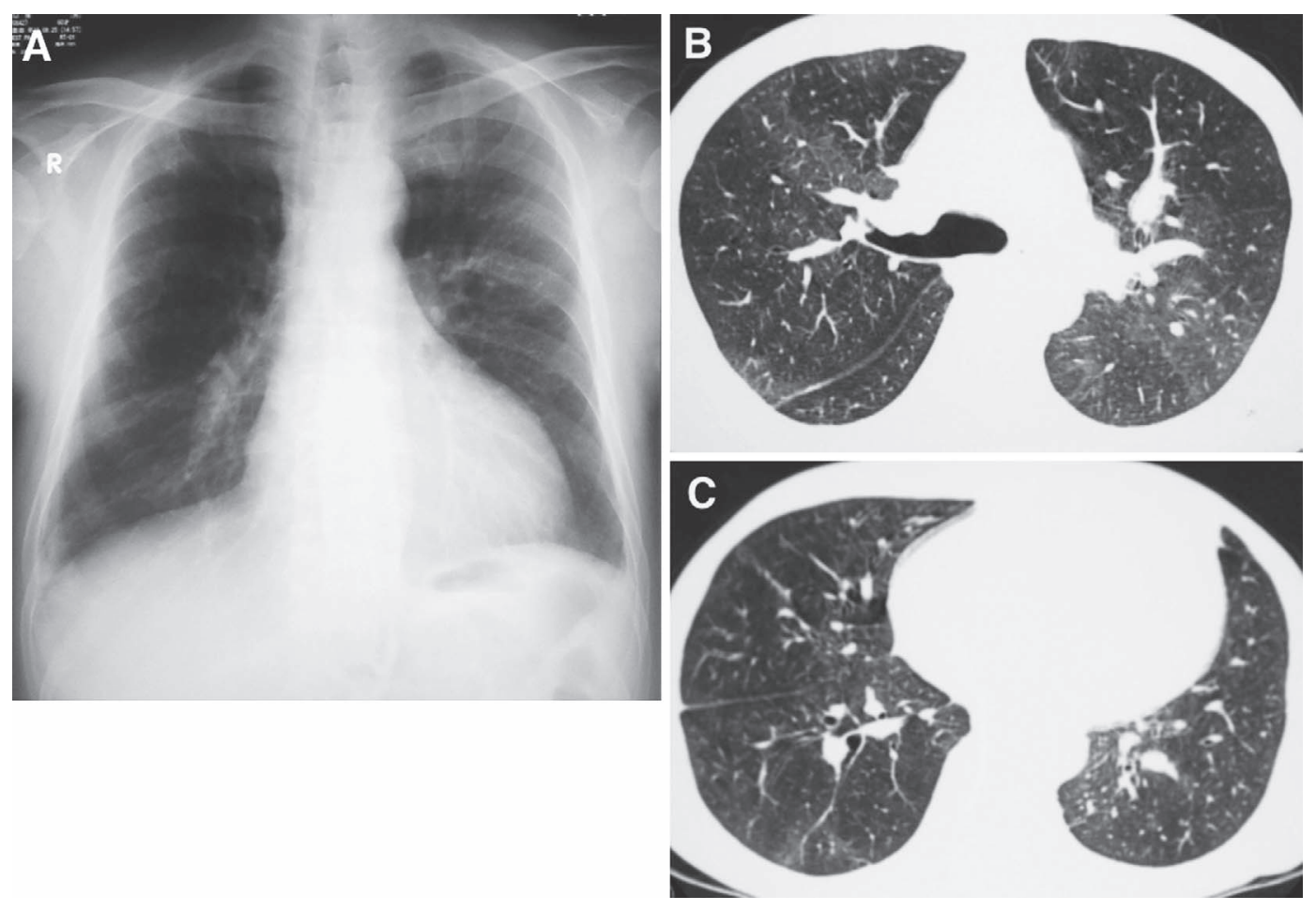

Figure 1. Chest X-ray shows infiltrative shadow in the left upper lung field with cardiomegaly (A). High-resolution CT (HRCT) scans demonstrate mosaic attenuation (B and C).

$\mathrm{HCO}_{3}^{-}, 26.0 \mathrm{mmol} / \mathrm{L}$ ) were slightly improved (Fig. 3). The BNP level was decreased to $157.1 \mathrm{pg} / \mathrm{mL}$. Infiltration on chest $\mathrm{X}$ ray showed improvement, but slight mosaic attenuation on HRCT remained (Supplement Fig. 2).

\section{Discussion}

There might be several explanations for an association between interstitial pneumonia and pulmonary thromboembolism. First, both of them share some etiology including environmental, host or genetic factors (6-9). Second, systemic inflammation is associated with alterations in the hemostatic balance, including activation of coagulation and suppression of fibrinolysis. From the standpoint of hemostatic abnormality, a nationwide cohort study showed that ever-diagnosed venous thromboembolism was associated with incidence of interstitial pneumonia, particularly among those never treated with anticoagulants (4). Theoretically, the authors had a simple explanation: individuals with procoagulant state could continuously develop clinically unnoticed small pulmonary emboli leading to progressive lung fibrosis and ultimately interstitial lung disease. In support of this finding, they have shown that homozygotes for the coagulation factor V R506Q (i.e. factor V Leiden) polymorphism have an increased risk of venous thromboembolism and suffer from severe dyspnea, reduced lung function, and increased lung function decline (9). Furthermore, anticoagulant therapy appears to be beneficial in the treatment of lung fibrosis (10-14). From the standpoint of systemic inflammation, it is reported that urokinase-type plasminogen activator (u-PA) and antithrombin III (AT-III) were decreased or plas- minogen activator-inhibitor 1 (PAI-1) and $\alpha 2$-plasmin inhibitor (PI) levels were increased in severe pneumonia $(15,16)$. In addition, it is possible that exertional dyspnea and hypoxia due to interstitial pneumonia causes decreased mobility, resulting in deep-vein thrombosis. However, it has remained controversial whether venous thromboembolism causes interstitial pneumonia, or vice versa.

The finding of a mosaic attenuation pattern at HRCT, which consists of low and ground-glass attenuation, occurred more often in patients with small airway disease [cellular bronchiolitis or, less commonly, constrictive bronchiolitis (bronchiolitis obliterans)], interstitial pneumonia (extrinsic allergic alveolitis), or chronic pulmonary thromboembolism (CPTE) $(17,18)$. In patients who have CPTE, mosaic attenuation patterns on HRCT are especially common and are often sufficiently characteristic to suggest the diagnosis $(17,18)$. In vascular diseases, it is thought that regional alteration in pulmonary blood flow is the final mechanism; reduced and increased attenuation areas may be attributed to obstructed pulmonary blood flow and regional hyperperfusion, respectively $(17,19)$. Regarding the pathologic characteristics of CPTE, while vascular lesions in pulmonary vascular disease have been reported (20), parenchymal findings have never been reported. Inconsistent with blood flow theory, in the present case, the biopsy specimen at one site showed focal infarct with surrounding homogeneous mononuclear cell infiltrates, while the other site revealed slightly more alveolitis without infarction than with infarction. It is reported that reactive epithelial changes are often present at the margin of pulmonary infarction (21). It is possible that inflammatory cells infiltrate the alveolar intersti- 


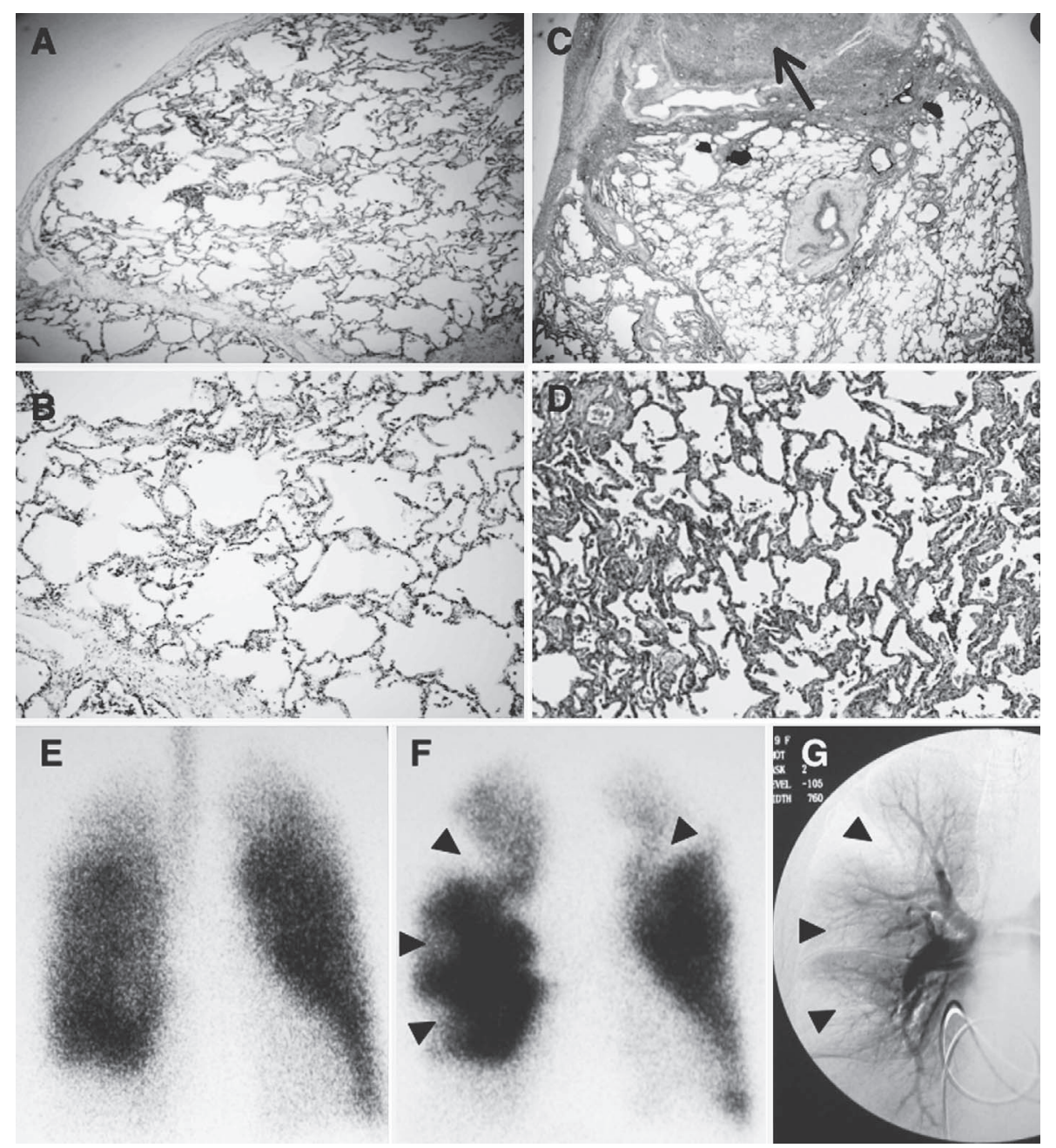

Figure 2. Surgical lung biopsy from right S3 (A, B) and S8 (C, D). S3 reveals homogeneous slight mononuclear cell infiltrates. S8 reveals focal infarct (arrow) with surrounding homogeneous mild mononuclear cell infiltrates (A and $C$ : original magnification $\times 20, B$ and $D$ : original magnification $\times 100) .{ }^{81 \mathrm{~m} K r}$ ventilation $(\mathrm{E})$ and ${ }^{99 \mathrm{~m}} \mathrm{Tc}$ perfusion $(\mathrm{F})$ scans, anterior view reveals $\mathrm{V} / \mathrm{Q}$ mismatch. Right pulmonary angiography (G) shows inadequate artery flow corresponding to mismatch area of scintigraphy (arrowhead).

num through the process of repeated long-term small infarcts. Pathologically, degrees of alveolar inflammation are commonly associated with ground-glass attenuation on HRCT. This discrepancy between blood flow theory and our pathological findings remains to be clarified.

Air trapping is commonly seen in chronic pulmonary embolism and is found in areas of relative hypoperfusion, which may be the cause of mosaic pattern $(22,23)$. In the present case, since the patient showed increased RV/TLC on admission, he might have peripheral airway obstruction. Anticoagulant therapy improved not only RV/TLC but also the extent of mosaic pattern on HRCT. Thus, mosaic pattern could consist of both of hypoperfusion and peripheral airway obstruction.

Pathological findings in the present case resembled cellular non-specific interstitial pneumonia (NSIP). Several studies showed that extrinsic allergic alveolitis is suspected in a patient with radiologically mosaic pattern on HRCT and with pathologically NSIP pattern $(24,25)$. However, in our case, extrinsic allergic alveolitis was excluded due to the absence of elevated BAL lymphocytes and the typical history including exposure to a causative agent and delayed postexpositional symptoms.

In idiopathic NSIP, dyspnea, cough, and inspiratory crackles were the most common symptoms and signs. On HRCT, the lower zones are predominantly involved with a reticular pattern with traction bronchiectasis and volume loss in most cases (26). Moreover, it is reported that markers for interstitial pneumonia, serum KL-6 and SP-D levels are elevated in patients with idiopathic NSIP (27). Thus, we did not consider this condition as idiopathic NSIP.

In conclusion, we described a case of CPTE, radiographically showing mosaic attenuation and pathologically showing homogenous cellular alveolitis. This case provides support for the close relationship between interstitial pneumonia and an impaired coagulation system.

The authors state that they have no Conflict of Interest (COI). 


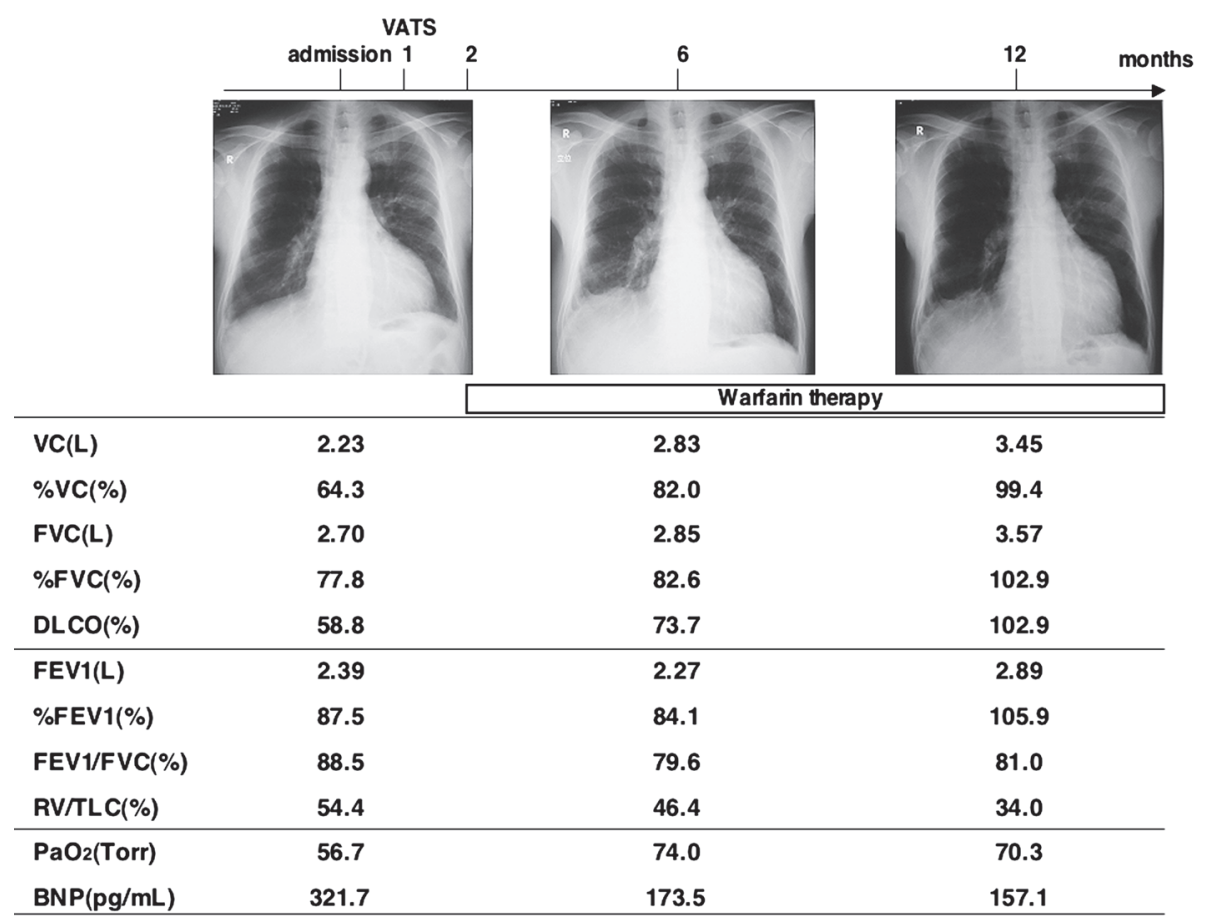

Figure 3. Clinical course.

The ethics committee of our hospital approved this report, and informed consent was obtained according to the hospital's guidelines.

\section{Acknowledgement}

We thank Dr. Thomas V. Colby (Department of Laboratory Medicine and Pathology, Mayo Clinic Scottsdale, Scottsdale, AZ, USA) for his comments on pathological findings.

\section{References}

1. Panos RJ, Mortenson RL, Niccoli SA, King TE Jr. Clinical deterioration in patients with idiopathic pulmonary fibrosis: causes and assessment. Am J Med 88: 396-404, 1990.

2. Nathan SD, Barnett SD, Urban BA, Nowalk C, Moran BR, Burton N. Pulmonary embolism in idiopathic pulmonary fibrosis transplant recipients. Chest 123: 1758-1763, 2003.

3. Hubbard RB, Smith C, Le Jeune I, Gribbin J, Fogarty AW. The association between idiopathic pulmonary fibrosis and vascular disease: a population-based study. Am J Respir Crit Care Med 178: 1257-1261, 2008.

4. Sode BF, Dahl M, Nielsen SF, Nordestgaard BG. Venous thromboembolism and risk of idiopathic interstitial pneumonia: a nationwide study. Am J Respir Crit Care Med 181: 1085-1092, 2010.

5. Makinodan K, Itoh T, Tomoda K, et al. Acute pulmonary thromboembolism associated with interstitial pneumonia. Intern Med 47: 647-650, 2008.

6. Taskar VS, Coultas DB. Is idiopathic pulmonary fibrosis an environmental disease? Proc Am Thorac Soc 3: 293-298, 2006.

7. Hubbard R, Venn A. Adult height and cryptogenic fibosing alveolitis: a case-control study using the UK General Practice Research Database. Thorax 55: 864-866, 2000.

8. Juul K, Tybjaerg-Hansen A, Schnohr P, Nordestgaard BG. Factor $\mathrm{V}$ Leiden and the risk for venous thromboembolism in the adult Danish population. Ann Intern Med 140: 330-337, 2004.

9. Juul K, Tybjaerg-Hansen A, Mortensen J, Lange P, Vestbo J, Nordestgaard BG. Factor V Leiden homozygosity, dyspnea, and reduced pulmonary function. Arch Intern Med 165: 2032-2036,
2005.

10. Howell DC, Goldsack NR, Marshall RP, et al. Direct thrombin inhibition reduces lung collagen, accumulation, and connective tissue growth factor mRNA levels in bleomycin-induced pulmonary fibrosis. Am J Pathol 159: 1383-1395, 2001.

11. Yasui H, Gabazza EC, Tamaki S, et al. Intratracheal administration of activated protein $\mathrm{C}$ inhibits bleomycin-induced lung fibrosis in the mouse. Am J Respir Crit Care Med 163: 1660-1668, 2001.

12. Günther A, Lübke N, Ermert M, et al. Prevention of bleomycininduced lung fibrosis by aerosolization of heparin or urokinase in rabbits. Am J Respir Crit Care Med 168: 1358-1365, 2003.

13. Kijiyama N, Ueno H, Sugimoto I, et al. Intratracheal gene transfer of tissue factor pathway inhibitor attenuates pulmonary fibrosis. Biochem Biophys Res Commun 339: 1113-1119, 2006.

14. Kubo H, Nakayama K, Yanai M, et al. Anticoagulant therapy for idiopathic pulmonary fibrosis. Chest 128: 1475-1482, 2005.

15. Günther A, Mosavi $P$, Heinemann $S$, et al. Alveolar fibrin formation caused by enhanced procoagulant and depressed fibrinolytic capacities in severe pneumonia. Comparison with the acute respiratory distress syndrome. Am J Respir Crit Care Med 161: 454$462,2000$.

16. Agapakis DI, Tsantilas D, Psarris $P$, et al. Coagulation and inflammation biomarkers may help predict the severity of communityacquired pneumonia. Respirology 15: 796-803, 2010.

17. Worthy SA, Müller NL, Hartman TE, Swensen SJ, Padley SP, Hansell DM. Mosaic attenuation pattern on thin-section CT scans of the lung: differentiation among infiltrative lung, airway, and vascular diseases as a cause. Radiology 205: 465-470, 1997.

18. Bergin CJ, Rios G, King MA, Belezzuoli E, Luna J, Auger WR. Accuracy of high-resolution CT in identifying chronic pulmonary thromboembolic disease. AJR Am J Roentgenol 166: 1371-1377, 1996.

19. King MA, Bergin CJ, Yeung DW, et al. Chronic pulmonary thromboembolism: detection of regional hypoperfusion with CT. Radiology 191: 359-363, 1994.

20. Wagenvoort CA. Lung biopsy specimens in the evaluation of pulmonary vascular disease. Chest 77: 614-625, 1980.

21. Bewtra C, Dewan N, O'Donahue WJ Jr. Exfoliative sputum cytology in pulmonary embolism. Acta Cytol 27: 489-496, 1983. 
22. Arakawa H, Kurihara Y, Sasaka K, Nakajima Y, Webb WR. Air trapping on CT of patients with pulmonary embolism. AJR Am J Roentgenol 178: 1201-1207, 2002.

23. Arakawa H, Stern EJ, Nakamoto $T$, Fujioka $M$, Kaneko $N$, Harasawa H. Chronic pulmonary thromboembolism. Air trapping on computed tomography and correlation with pulmonary function tests. J Comput Assist Tomogr 27: 735-742, 2003.

24. Silva CI, Müller NL, Lynch DA, et al. Chronic hypersensitivity pneumonitis: differentiation from idiopathic pulmonary fibrosis and nonspecific interstitial pneumonia by using thin-section CT.
Radiology 246: 288-297, 2008.

25. Lima MS, Coletta EN, Ferreira RG, et al. Subacute and chronic hypersensitivity pneumonitis: histopathological patterns and survival. Respir Med 103: 508-515, 2009.

26. Travis WD, Hunninghake G, King TE Jr, et al. Idiopathic nonspecific interstitial pneumonia: report of an American Thoracic Society project. Am J Respir Crit Care Med 177: 1338-1347, 2008.

27. Ishii H, Mukae H, Kadota J, et al. High serum concentrations of surfactant protein A in usual interstitial pneumonia compared with non-specific interstitial pneumonia. Thorax 58: 52-57, 2003.

(C) 2011 The Japanese Society of Internal Medicine http://www.naika.or.jp/imindex.html 